\title{
Sub-acute administration of (S)-dimethyl 2-(3-(phenyltellanyl) propanamido) succinate induces toxicity and oxidative stress in mice: unexpected effects of $\mathrm{N}$-acetylcysteine
}

\author{
Daiane F Meinerz ${ }^{1}$, Bruna Comparsi ${ }^{1}$, Josiane Allebrandt ${ }^{1}$, Douglas Oscar Ceolin Mariano ${ }^{1}$, Danúbia B dos Santos ${ }^{3}$, \\ Ana Paula Pegoraro Zemolin², Marcelo Farina ${ }^{3}$, Alcir Luiz Dafre ${ }^{3}$, João B T Rocha', Thaís Posser ${ }^{1,2}$ and \\ Jeferson L Franco ${ }^{1,2^{*}}$
}

\begin{abstract}
The organic tellurium compound (S)-dimethyl 2-(3-(phenyltellanyl) propanamide) succinate (TeAsp) exhibits thiol-peroxidase activity that could potentially offer protection against oxidative stress. However, data from the literature show that tellurium is a toxic agent to rodents. In order to mitigate such toxicity, N-acetylcysteine (NAC) was administered in parallel with TeAsp during 10 days. Mice were separated into four groups receiving daily injections of (A) vehicle (PBS $2.5 \mathrm{ml} / \mathrm{kg}$, i.p. and DMSO $1 \mathrm{ml} / \mathrm{kg}$, s.c.), (B) NAC (100 mg/kg, i.p. and DMSO s.c.), (C) PBS i.p. and TeAsp $(92.5 \mu \mathrm{mol} / \mathrm{kg}$, s.C), or (D) NAC plus TeAsp. TeAsp treatment started on the fourth day. Vehicle or NAC-treated animals showed an increase in body weight whereas TeAsp caused a significant reduction. Contrary to expected, NAC co-administration potentiated the toxic effect of TeAsp, causing a decrease in body weight. Vehicle, NAC or TeAsp did not affect the exploratory and motor activity in the open-field test at the end of the treatment, while the combination of NAC and TeAsp produced a significant decrease in these parameters. No DNA damage or alterations in cell viability were observed in leukocytes of treated animals. Treatments produced no or minor effects on the activities of antioxidant enzymes catalase, glutathione peroxidase and glutathione reductase, whereas the activity of the thioredoxin reductase was decreased in the brain and increased the liver of the animals in the groups receiving TeAsp or TeAsp plus NAC. In conclusion, the toxicity of TeAsp was potentiated by NAC and oxidative stress appears to play a central role in this process.
\end{abstract}

\section{Introduction}

Elemental tellurium $(\mathrm{Te})$ is a rare trace element that is widely used in the manufacture of ceramics, glass, semiconductors, and metals (Ogra et al. 2008). Despite the growing use of organotellurium compounds in chemistry and biochemistry and the consequent increase in the risk of occupational and environmental exposure to these substances, data about their toxicity are scarce in the literature. In fact, these compounds have been shown to be promising and useful alternatives for numerous synthetic operations

\footnotetext{
* Correspondence: jefersonfranco@unipampa.edu.br

1 Departamento de Química, Centro de Ciências Naturais e Exatas,

Universidade Federal de Santa Maria, Santa Maria, RS CEP 97105-900, Brazil ${ }^{2}$ Campus São Gabriel, Universidade Federal do Pampa, São Gabriel, RS CEP 97300-000, Brazil

Full list of author information is available at the end of the article
}

in organic synthesis (Petragnani 1994; Comasseto and Gariani 2009). Previous studies demonstrated that organotellurium compounds are potentially toxic and lethal to rodents at low doses (Meotti et al. 2003; Savegnago et al. 2006) Indeed, tellurides can cause cytotoxicity (Sailer et al. 2004), hepatotoxicity (Meotti et al. 2003), neurotoxicity (Nogueira et al. 2001; Nogueira et al. 2002), teratogenicity (Stangherlin et al. 2005) and genotoxicity (Santos et al. 2009a, b). Moreover, these compounds can inhibit sulfhydryl-containing enzymes, such as the $\mathrm{Na}^{+} / \mathrm{K}^{+}$-ATPase (Borges et al. 2005), the $\delta$-aminolevulinic acid dehydratase (Maciel et al. 2000; Nogueira et al. 2003) and the squaleno monooxigenase (Laden and Porter 2001).

The mechanisms of toxicity by organotellurium compounds may be related to the oxidation of thiol groups of 
important biomolecules (Nogueira et al. 2004), the replacement of selenium in selenoproteins (such as thioredoxin reductase) (Engman et al. 2000), and the capacity of Te compounds to induce the formation of reactive oxygen species (ROS) (Chen et al. 2001; Funchal et al. 2011; de Andrade et al. 2010). On the other hand, pharmacological and/or antioxidants properties of tellurium compounds have also been reported in the literature (Ávila et al. 2011; Avila et al. 2012), including antitumor and chemoprotective effects (Engman et al. 2000; Cunha et al. 2005), and glutathione peroxidase (GPx) like activity (Engman et al. 1994). The existence of toxic and beneficial effects of tellurium compounds brings out the need for further research on their toxicological and pharmacological mechanisms of action.

The compound studied on the present work, $(S)$-dimethyl 2-(3-(phenyltellanyl) propanamido) succinate (TeAsp), is a new telluroamino acid derivative of aspartic acid that was found to be the most potent mimetic of GPx among 20 newly synthesized derivatives (Braga et al. 2009; Alberto et al. 2009) presenting antioxidant properties in vitro. However, when administered to rodents this compound showed potent genotoxic and mutagenic actions (Meinerz et al. 2011).

In order to elucidate the mechanisms mediating the biological effects of TeAsp, the present study aimed to investigate putative mechanisms underlying the toxicity of TeAsp in vivo. We assessed behavioral and oxidative stress parameters in mice, including the modulation of antioxidant enzymatic defense systems by TeAsp in different tissues. We also evaluated the potential protective effect of $\mathrm{N}$-acetylcysteine (NAC), a thiol-containing antioxidant that is largely used to mitigate the effects of oxidative stress-causing agents (Flora et al. 2004) due to its ability to stimulate glutathione (GSH) synthesis.

\section{Materials and methods Chemicals}

The chemical structure of TeAsp is shown in Figure 1. This compound was synthesized by the method previously

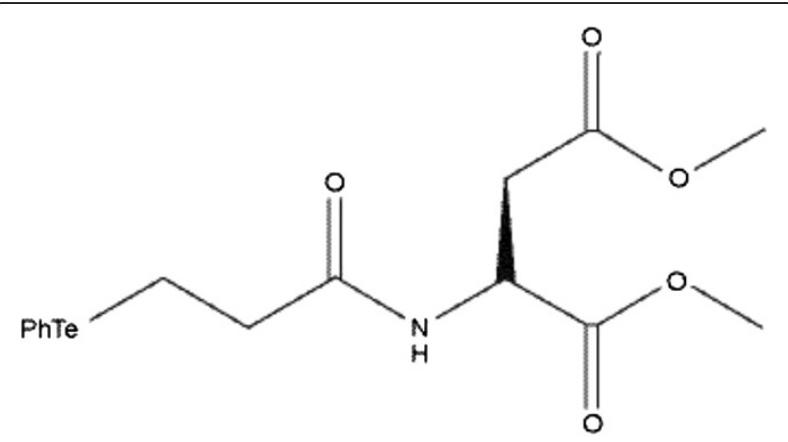

Figure 1 The chemical structure of (S)-dimethyl

2-(3-(phenyltellanyl) propanamido) succinate (TeAsp). described by Braga et al. (2009). TeAsp solutions were prepared in dimethyl sulfoxide (DMSO). All reagents used were purchased from Sigma (São Paulo, Brazil).

\section{Animals}

Swiss adult male mice (45-days old), weighing 30-40 g, were used in the experiments. All mice were obtained from and maintained in the animal facilities of UFSM. Mice (5 per group) were kept in separate cages on 12-hour light/dark cycle, controlled temperature $\left(22 \pm 3^{\circ} \mathrm{C}\right)$ and $a d$ libitum access to food and water. The animals were used according to the guidelines of the institutional board for animal care and use (CEUA) of the Federal University of Santa Maria, Brazil (23081.002435/2007-16).

\section{Exposure (animals treatment)}

Mice were separated into four groups, with 5 animals each, receiving daily injections of: (A) vehicles of NAC and TeAsp respectively (PBS $2.5 \mathrm{ml} / \mathrm{kg}$, i.p. plus DMSO $1 \mathrm{ml} / \mathrm{kg}$ (0.1\%), s.c.); (B) NAC (100 mg/kg, i.p.) plus DMSO s.c.); (C) PBS i.p. plus TeAsp (92.5 $\mu \mathrm{mol} / \mathrm{kg}$, s.c.); or (D) NAC, i.p plus TeAsp, s.c. Treatment with TeAsp started just after the third day of NAC administration, using a dose equivalent to $50 \%$ of the previously described $\mathrm{LD}_{50}(185 \mu \mathrm{mol} / \mathrm{kg})$ (Meinerz et al. 2011).

The animals were weighted daily and monitored for the appearance of signs of toxicity, such as exhalation of garlic odor, partial or total paralysis of lower limbs, diarrhea, tremors, hair loss, and weight loss. No signs of toxicity were apparent throughout the period of treatment. Behavioral evaluation was performed 24 hours after the end of the treatment.

\section{Open field test}

One day after the last injection the animals were acclimated to the experimental room for at least 2 hours prior to the beginning of the open field test. Open field tests were carried out in soundproof room without any human interference, as described elsewhere (Kim et al. 2000).

\section{Antioxidant enzymes assays and protein determination}

On the $11^{\text {th }}$ day, following the behavior evaluation, the animals were anesthetized with ethyl ether and blood samples were collected by heart puncture for leukocytes viability and comet assay. The mice were then euthanized; the brain and liver were dissected, weighted, homogenized in a Potter- Elvehjem tissue homogenizer with $50 \mathrm{mM}$ Tris- $\mathrm{HCl}$ buffer, $\mathrm{pH} 7.4$ and centrifuged at $4000 \times \mathrm{g}$ for $10 \mathrm{~min}$ at $4^{\circ} \mathrm{C}$. The low speed supernatant (S1) was collected and kept on ice until used for the enzyme assays.

The activities of the antioxidant enzymes catalase (CAT) (Aebi 1984), GPx (Wendel 1981), glutathione reductase (GR) (Carlberg and Mannervik 1985) and thioredoxin reductase (TrxR) (Holmgren and Björnstedt 
1995) were determined in the S1 fraction of mice brain and liver as described elsewhere.

Protein concentration was determined by the method of Lowry et al. (1951), using bovine serum albumin as the standard.

\section{Leukocyte DNA damage and viability}

Leukocytes were isolated as describes in (Santos et al. 2009a) and the cell density was adjusted to $2 \times 10^{6}$ leukocytes/ml by dilution with HBSS/heparin. The percentage of viable leukocytes was determined using the Trypan blue exclusion method counting on a hemocytometer (Mischell and Shiingi 1980).

The comet assay was carried out following previously published procedures (Santos et al. 2009a). The slides were analyzed by at least two observers blinded to the experiment. One hundred cells per sample were randomly selected and visually scored based on tail intensity into five classes ranging from 0 (undamaged) to 4 (maximally damaged). The damage index (DI) is based on the length of migration and on the amount of DNA in the tail was calculated as follows:

$$
\mathrm{DI}=\mathrm{n} 1+2 \mathrm{n} 2+3 \mathrm{n} 3+4 \mathrm{n} 4
$$

where, $n 1$ represents the number of cells with level 1 of damage; $n 2$, number of cells with level 2 of damage; $n 3$, number of cells with level 3 of damage; n4, number of cells with level 4 of damage.

\section{Statistical analysis}

Data were analyzed using one or two way analysis of variance (ANOVA) followed by Newman-Keuls or Bonferroni post hoc test when appropriate. Differences were considered significant when $\mathrm{p}<0.05$.

\section{Results}

\section{Body weight gain}

No mortality occurred after repeated administration of NAC and/or TeAsp to mice. As expected, the animals' body weight gains increased (17\%) with time (Figure 2). Treatment with TeAsp for seven days (days 4-10) caused a significant decrease in body weight gain already in the fourth day after the first administration (day 7), producing a continuous decrease until the end of the experiment, when animals weighted 6\% less. Animals treated with NAC followed the same trend. Compared to control (vehicle-treated) animals at the end of the treatment TeAsp-treated mice presented an average 23\% lower body weight. Instead of decreasing TeAsp toxicity, NAC potentiated its effect on weight loss, producing an additional $8 \%$ decrease in body weight (14\% total).

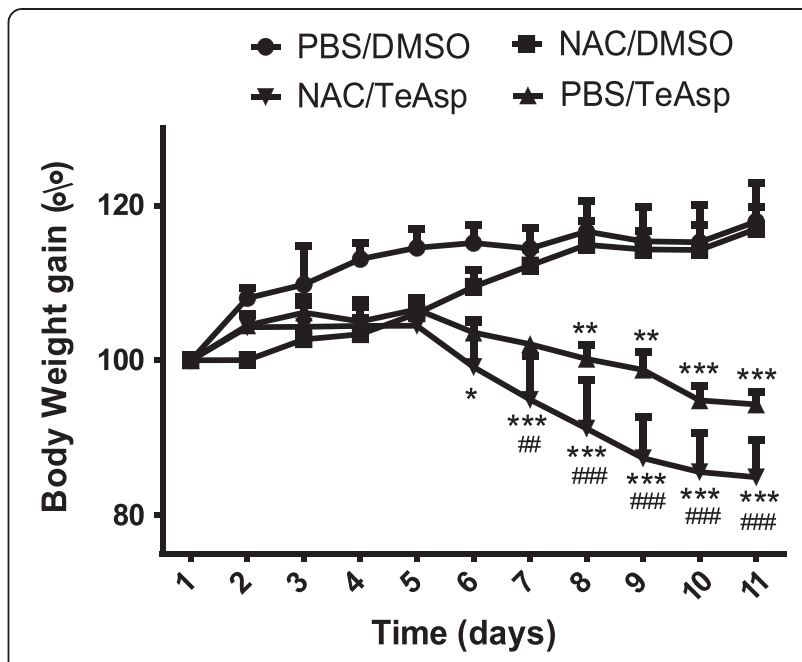

Figure 2 Effect of (S)dimethyl 2-(3 (phenyltellanyl) propanamido) succinate (TeAsp) on the body weight gain of adult mice. Data are reported as percentage \pm S.E.M. of 5 animals per group. Two way ANOVA followed by Bonferroni posttest. * $(p<0.05),{ }^{* *}(p<0.01)$ or

*** $(p<0.001)$ represent significant differences from PBS/DMSO and

\#\# $(p<0.01)$ or ${ }^{\# \# \# ~}(p<0.001)$ means significant differences from NAC/DMSO group.

\section{Open field test}

To assess whether the treatment with NAC and/or compound could cause changes in exploratory or locomotor behavior of animals, the mice were exposed to open field test and we observed that treatment with vehicle (PBS or DMSO), NAC or TeAsp did not cause any alterations in this behavior. However, when the mice were treated with TeAsp plus NAC, 60\% decrease in locomotion and 35\% decrease in exploratory behavior were observed (Figure 3).

\section{Antioxidant enzymes activity}

Considering that the compound caused alterations on weigh gain and behavior of the animals exposed, we carried out the antioxidant enzymes activity to determine if the toxicity could be related to oxidative stress in brain and liver.

Brain and liver CAT and GPx (Table 1) activities were not altered by the treatments. Liver GR activity (Table 1) was elevated only in mice treated with TeAsp plus NAC.

The brain TrxR activity (Figure 4) was significantly decreased following the treatment with TeAsp $(\mathrm{p}<0.001)$ or TeAsp plus NAC $(\mathrm{p}<0.01)$. In contrast, the hepatic TrxR activity increased following the treatment with either TeAsp alone $(\mathrm{p}<0.05)$ or in combination with NAC $(\mathrm{p}<0.001)$.

\section{Cell viability and DNA damage}

Another sign of toxicity is related to damage to DNA and cytoxicity that in this study were evaluated by comet assay and cell viability. In the mice treated in this study 

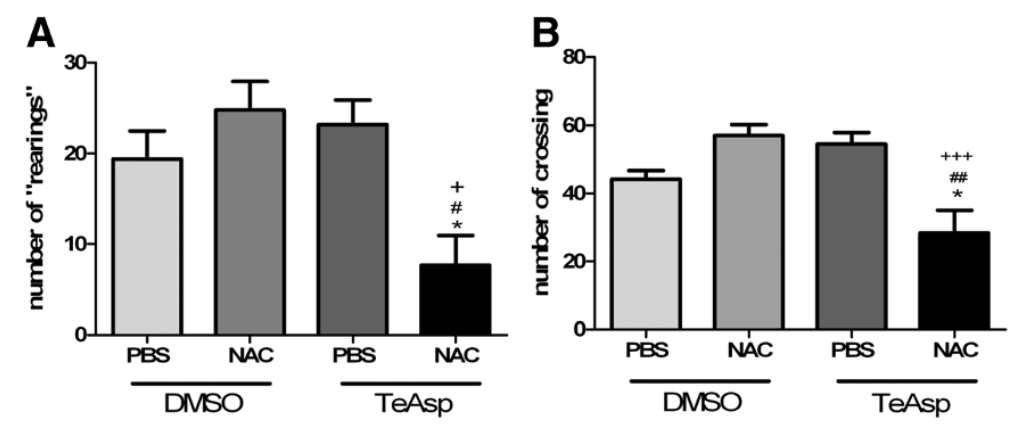

Figure 3 Effects of (S)dimethyl 2-(3 (phenyltellanyl) propanamido) succinate (TeAsp) on open field test, number of rearings (A) and number of crossing (B) from adult mice. Data are reported as mean \pm S.E.M. of 5 animals per group. One way ANOVA followed by Newman-Keuls Multiple Comparison Test. * $(p<0.05)$ represents significant differences from PBS/DMSO group; ${ }^{\#}(p<0.05)$ and ${ }^{\# \#}(p<0.01)$ represents significant differences from NAC/DMSO group and ${ }^{+}(p<0.05)$ and ${ }^{+++}(p<0.001)$ represents significant difference from PBS/TeAsp.

the administration of TeAsp alone or in combination with NAC did not cause cytotoxicity or genotoxicity to mice leukocytes (Table 2).

\section{Discussion}

In the present study, we show that the administration of TeAsp for 7 days to mice induces significant changes on body weight, locomotor and exploratory behavior, as well as on the antioxidant enzymatic system. Previous studies have shown the antioxidant properties of Te compounds (Ávila et al. 2007; Ávila et al. 2010; Avila et al. 2012). Two previous studies investigated the effects TeAsp in vitro (Braga et al. 2009; Meinerz et al. 2011). However, even though presenting antioxidant properties in vitro, organotellurium compounds have been found to be toxic in vivo and in vitro (Sailer et al. 2004; Santos et al. 2009a, b; Funchal et al. 2011; Schiar et al. 2009; Pessoto et al. 2007). In a previous study, we found that TeAsp causes a significant mutagenic and genotoxic effect in mice when the doses administered are close to the $\mathrm{LD}_{50}$ (Meinerz et al. 2011). However, the mechanisms of TeAsp toxicity are still unclear. In the presented study, mice treated with TeAsp exhibited overt signs of toxicity, which included a remarkable weight loss and garlic odor exhalation. In fact, garlic odor exhalation is considered a hallmark of intoxication caused by tellurium compounds (Taylor 1996). Considering the chemistry of tellurium compounds, the oxidation of Te (II) to $\mathrm{Te}(\mathrm{IV})$ and its interaction with nucleophilic centers of biomolecules is thought to underlie the toxicity of tellurium containing organic moieties. In this context, considering that tellurium compounds can be toxic due to depletion of cellular thiol groups (Deuticke et al. 1992), we attempted to reduce TeAsp toxicity by using the thiol donor (NAC). There is abundant evidence regarding the use of NAC as an antioxidant. It is a thiol-containing molecule that has been widely used for promoting GSH synthesis (Moldeus et al. 1986; Sathish et al. 2011; Atkuri et al. 2007). The rationale for the use of NAC in the present study was that it would be able to protect against the deleterious effects of TeAsp. However, instead of protecting, we found that NAC potentiated the toxic effects of TeAsp.

Regarding the open-field behavior results, mice treated with TeAsp alone showed no difference compared to control animals. However, the mice treated with NAC plus TeAsp showed a significant decrease in locomotor activity and exploratory behavior. These results corroborate data

Table 1 Effect of (S)-dimethyl 2-(3-(phenyltellanyl) propanamido) succinate (TeAsp) on the activity of the antioxidant enzymes Catalase, Glutathione Peroxidase (GPx) and Glutathione Reductase (GR) from adult mice brain and liver

\begin{tabular}{|c|c|c|c|c|c|c|}
\hline \multirow[t]{2}{*}{ Treatment } & \multicolumn{2}{|c|}{ Catalase activity $^{a}$} & \multicolumn{2}{|c|}{ GPx activity ${ }^{b}$} & \multicolumn{2}{|c|}{ GR activity ${ }^{b}$} \\
\hline & Brain & Liver & Brain & Liver & Brain & Liver \\
\hline PBS/DMSO & $0.55 \pm 0.04$ & $4.44 \pm 0.7$ & $8.12 \pm 0.6$ & $93.0 \pm 3.6$ & $21.05 \pm 0.1$ & $38.6 \pm 4.3$ \\
\hline NAC/DMSO & $0.66 \pm 0.1$ & $5.19 \pm 0.8$ & $9.09 \pm 0.6$ & $105.1 \pm 9.2$ & $25.58 \pm 2.55$ & $45.6 \pm 3.9$ \\
\hline PBS/TeAsp & $0.57 \pm 0.05$ & $3.72 \pm 0.5$ & $8.47 \pm 0.4$ & $91.8 \pm 2.5$ & $18.94 \pm 0.65$ & $44.8 \pm 5.1$ \\
\hline NAC/TeAsp & $0.64 \pm 0.1$ & $3.38 \pm 0.32$ & $7.06 \pm 0.65$ & $97.1 \pm 7.2$ & $\begin{array}{c}19.86 \\
2.0\end{array}$ & $62.5 \pm 5.9^{*}$ \\
\hline
\end{tabular}

Results are mean \pm S.E.M., $n=5$ per group. One way ANOVA followed by Newman-Keuls Multiple Comparison Test.

*Values significantly different from the PBS/DMSO group with $\mathrm{p}<0.05$.

${ }^{a}$ Catalase activity is expressed as $\mu \mathrm{mol} \mathrm{H}_{2} \mathrm{O}_{2} / \mathrm{min} / \mathrm{mg}$ of protein.

${ }^{\mathrm{b}} \mathrm{GPx}$ activity and GR activity are expressed as $\mathrm{nmol} \mathrm{NADPH} / \mathrm{min} / \mathrm{mg}$ of protein. 

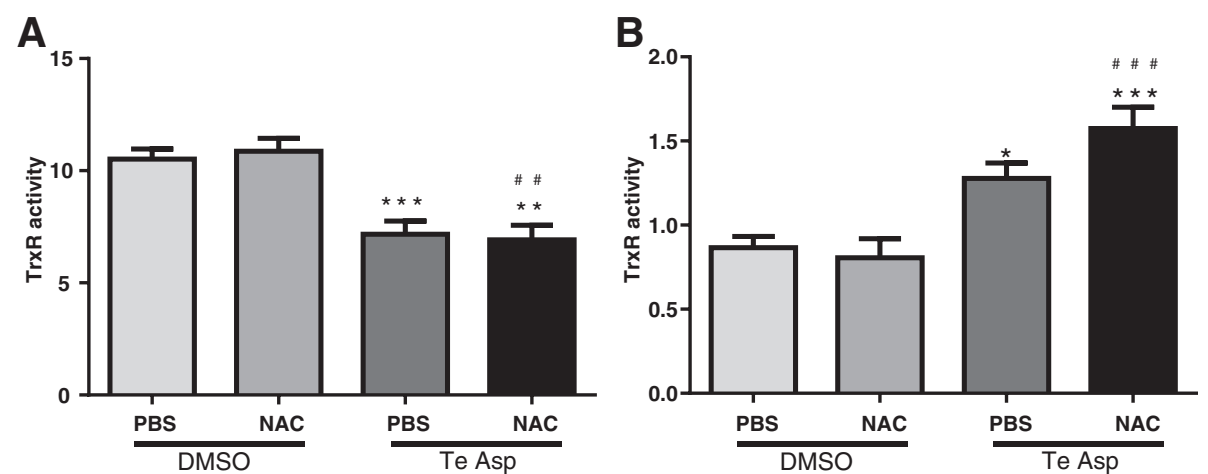

Figure 4 Effects of (S)dimethyl 2-(3 (phenyltellanyl) propanamido) succinate (TeAsp) on TrxR activity in brain (A) and liver (B) of mice. The results are expressed as TNB/min/mg of protein and data are reported as mean \pm S.E.M. of 5 animals per group. One way ANOVA followed by Newman-Keuls Multiple Comparison Test. ${ }^{*}(p<0.05),{ }^{* *}(p<0.01)$ or ${ }^{* * *}(p<0.001)$ represents significant differences from PBS/DMSO group; $\#(p<0.01)$ or \#\#\# $(p<0.001)$ represents significant differences from NAC/DMSO group.

from the literature that show that Te compounds usually exert toxic effects on the nervous system (Nogueira et al. 2002; Pinton et al. 2010). However, in the case of TeAsp, the toxic effect was observed only after concomitant treatment with NAC. We suggest that the thiol group of NAC could interact with the tellurium atom of TeAsp either by changing it to a more toxic compound or by forming a complex that could cause greater toxicity to cells of target organs. In fact, it was possible to observe an interaction between TeAsp and NAC by a spectroscopic approach using their absorption spectra between $200-800 \mathrm{~nm}$. In that experiment, NAC shifted the absorption spectra of TeAsp between 320-380 nm (data not shown). That indicates that NAC reacts with TeAsp, a fact that might be occurring in vivo as well.

Antioxidant enzymes are considered to be a primary defense that prevents macromolecules from oxidative damage (Subramanian and James 2010). Alterations in enzymatic antioxidant systems are frequently used as markers of toxicity induced by a variety of organic compounds, heavy metals, aging and disease (Liu et al. 2004; Franco et al. 2009; Ling et al. 2011). The brain is especially susceptible to oxidative stress due to its elevated

Table 2 Cell viability and DNA damage in leukocytes of TeAsp- treated mice

\begin{tabular}{lcc}
\hline Treatment & Viability (\%) & D.I. \\
\hline PBS/DMSO & $86.7 \pm 2.35$ & $12.25 \pm 1.65$ \\
NAC/DMSO & $86.8 \pm 3.91$ & $11.00 \pm 1.78$ \\
PBS/TeAsp & $91.7 \pm 2.50$ & $13.75 \pm 4.80$ \\
NAC/TeAsp & $94.8 \pm 0.85$ & $9.70 \pm 3.35$
\end{tabular}

Results are mean \pm S.E.M., $n=5$ per group. One way ANOVA followed by Newman-Keuls Multiple Comparison Test. Viability means the percentage of Trypan blue-negative cells.

D.I.: Damage index was calculated as follows: $\mathrm{DI}=\mathrm{n} 1+2 \mathrm{n} 2+3 \mathrm{n} 3+4 \mathrm{n} 4$. Where, $\mathrm{n} 1$ represents the number of cells with level 1 of damage; $\mathrm{n} 2$, number of cells with level 2 of damage; 33 , number of cells with level 3 of damage; $n 4$ number of cells with level 4 of damage. oxygen consumption (Noseworthy and Bray 1998). Accordingly, brain cells are equipped with an efficient antioxidant machinery, including the glutathione and thioredoxin systems, to dispose of the reactive species generated by high rates of aerobic metabolism (Dringen et al. 2005; Kudin et al. 2012). In this study, TeAsp did not alter the activity of most of the brain antioxidant enzymes tested (GR, GPx or CAT), even when concomitantly administered with NAC. The activity of the brain TrxR was, on the other hand, decreased following the treatment with TeAsp alone. According to previously published data, Te compounds can inhibit TrxR and cause cytotoxicity in vitro, probably due to the high affinity of Te compounds for the thiol and selenol groups found in TrxR (Engman et al. 2000; Engman et al. 2003). Inhibition of the Trx system is likely to further increase the brain's susceptibility to oxidative stress. Recent studies have demonstrated the crucial role of this antioxidant system in performing peroxide detoxification in the brain (Kudin et al. 2012). In line with this evidence, the inhibition of brain TrxR by TeAsp observed in this study might be, at least in part, considered a potential mechanism of neurotoxicity induced by this organotelluride.

Comparable to what we observed in the brain, liver catalase was also unchanged after the mice were exposed to TeAsp. However, an opposite effect was observed for GR and TrxR activities in liver. Previous reports have shown that acute exposure to oxidants frequently increases the activity of antioxidant enzymes as an adaptive response which, consequently, reduces the damage (Hilbert and Mohsenin 1996). GR and TrxR are known to be involved in the regeneration of GSH and thioredoxin, respectively (Meister and Anderson 1983; Arnér and Holmgren 2000). Our data showed that these enzymes were increased in the liver of treated animals. This result could indicate an up-regulation of the cellular thiol regenerating systems. In this way, the thiol oxidizing 
effect of TeAsp, as well as other organotellurides (Meinerz et al. 2011), could trigger a compensatory response to TeAsp-induced hepatic GSH and $\operatorname{Trx}(\mathrm{SH})_{2}$ oxidation.

The NF-E2-related factor 2 (Nrf2) is thought to be a pivotal regulator of the ARE-driven cellular defense against oxidative stress and its regulation appears to be cell specific (Lee et al. 2005). This transcription factor binds to the "antioxidant responsive element" - ARE (Nrf2ARE pathway) and has been shown to regulate the expression of several antioxidant proteins such as glutathione-S-transferase, GPX, GR, SOD, CAT and the thioredoxin system (Tanito et al. 2007; Hur and Gray 2011; Schülke et al. 2012). However, the positive or negative balance of Nrf2-ARE pathway activation depends on the combination of numerous factors. Several nuclear factors are shown to bind ARE, including c-Jun, c-Fos, Nrf1, Nrf2, MafG, MafK, among others (Jaiswal 2004; Dhakshinamoorthy et al. 2005). Moreover, the downregulation of the Nrf2-ARE pathway is not well understood. In this context, Nrf2 can be inactivated by Kelch-like ECH-associated protein 1 (Keap1) in the cytoplasm (Wang and Zhang 2009). In that same context, the Bach1 transcription factor has been shown to induce negative regulation of the Nrf2-ARE driven antioxidant response (Dhakshinamoorthy et al. 2005). Taking it all into account, one could suppose that the opposing responses such as the observed in our study between brain and liver GR and TrxR may be related to alternative regulation of the ARE-driven protective pathway in different tissues.

\section{Conclusion}

Summarizing, contrary to the hypothesized, NAC did not protect against TeAsp-induced toxicity in mice. On the contrary, NAC exacerbated the general and behavioral toxicity elicited by TeAsp. Although not addressed in this study, we may speculate that the exacerbation of TeAsp toxicity by NAC may be associated with the formation of intermediate(s) with higher toxicity (for instance, diphenyl ditelluride) or to the release of Te from the organic moiety to generate a more toxic inorganic form (Te (IV)). Additional studies are necessary to determine the precise mechanisms of TeAsp toxicity and its interaction with NAC. The elucidation of such mechanisms would contribute to understanding the events mediating the therapeutic and toxic effects of Tellurium compounds.

\section{Competing interests}

The authors declare that they have no competing interests.

\section{Authors' contributions}

DFM is the main author. BC, JA and DOCM participated in the animal handling and behavior experiments. BC, DBS and APPZ participated in the enzyme activity experiments. MF and ALD provided the chemical reagents for antioxidant enzyme activity assays and participated in the manuscript revision. JBT and TP participated in the manuscript edition and are responsible for FAPERGS-PRONEX and CNPq grants. All authors read and approved the final manuscript.

\section{Acknowledgments}

Authors thanks for financial support by FAPERGS, FAPERGS-PRONEX, CNPq, FINEP, and also by the revision of the manuscript by Dr. Marcelo Reis.

\section{Author details}

'Departamento de Química, Centro de Ciências Naturais e Exatas, Universidade Federal de Santa Maria, Santa Maria, RS CEP 97105-900, Brazil. ${ }^{2}$ Campus São Gabriel, Universidade Federal do Pampa, São Gabriel, RS CEP 97300-000, Brazil. ${ }^{3}$ Departamento de Bioquímica, Centro de Ciências Biológicas, Universidade Federal de Santa Catarina, Florianópolis, SC CEP 88040-900, Brazil.

Received: 30 November 2012 Accepted: 16 April 2013 Published: 24 April 2013

\section{References}

Aebi H (1984) Catalase in vitro. Methods Enzymol 105:121-126

Alberto EE, Soares LC, Sudati JH, Borges AC, Rocha JBT, Braga AL (2009) Efficient synthesis of modular amino acid derivatives containing selenium with pronounced GPx like activity. European J Org Chem 25:4211-4214

Arnér ESJ, Holmgren A (2000) Physiological functions of thioredoxin and thioredoxin reductase. Eur J Biochem 267:6102-6109

Atkuri KR, Mantovani JJ, Herzenberg LA, Herzenberg LA (2007) N- Acetylcysteine-a safe antidote for cysteine/glutathione deficiency. Curr Opin Pharmacol 7:355-359

Avila DS, Benedetto A, Au C, Manarin F, Erikson K, Soares FA, Rocha JB, Aschner M (2012) Organotellurium and organoselenium compounds attenuate $\mathrm{Mn}$-induced toxicity in C. elegans by preventing oxidative stress. Free Radic Biol Med 52:1903-1910

Ávila DS, Colle D, Gubert P, Palma AS, Puntel G, Manarin F, Noremberg S, Nascimento PC, Aschner M, Rocha JBT, Soares FAA (2010) A possible neuroprotective action of a vinylic telluride against $\mathrm{Mn}$-induced neurotoxicity. Toxicol Sci 115:194-201

Ávila DS, Gubert P, Dalla Corte CL, Alves D, Nogueira CW, Rocha JBT, Soares FAA (2007) A biochemical and toxicological study with diethyl 2-phenyl-2tellurophenyl vinylphosphonate in a subchronic intraperitoneal treatment in mice. Life Sci 80:1865-1872

Ávila DS, Palma AS, Colle D, Scolari R, Manarin F, da Silveira AF, Nogueira CW, Rocha JBT, Soares FAA (2011) Hepatoprotective activity of a vinylic telluride against acute exposure to acetaminophen. Eur J Pharmacol 661:92-10

Borges VC, Rocha JBT, Nogueira CW (2005) Effect of diphenyl diselenide, diphenyl ditelluride and ebselen on cerebral Na+K+ ATPase activity in rats. Toxicol 215:191-197

Braga AL, Alberto EE, Soares LC, Rocha JBT, Sudati JH, Roos DH (2009) Synthesis of telluroamino acid derivatives with remarkable GPx like activity. Org Biomol Chem 7:43-45

Carlberg I, Mannervik B (1985) Glutathione reductase. Methods Enzymol 113:484-490

Chen F, Vallyathan V, Castranova V, Shi X (2001) Cell apoptosis induced carcinogenic metals. Mol Cel Biochem 221:183-188

Comasseto JV, Gariani RA (2009) Biotransformations on organic selenides and tellurides: synthetic applications. Tetrahedron 65:8447-8459

Cunha LOR, Urano ME, Chagas JR, Almeida PC, Bincoletto C, Tersariol ILS, Comasseto JV (2005) Tellurium-based cysteine protease inhibitors: evaluation of novel organotellurium (IV) compounds as inhibitors of human cathepsin B. Bioorg Med Chem Lett 15:755-760

de Andrade RB, Gemelli T, Guerra RB, Funchal C, Wannmacher CM (2010) Inhibition of creatine kinase activity by 3-butyl-1-phenyl-2-(phenyltelluro)octen 1-one in the cerebral cortex and cerebellum of young rats. J Appl Toxicol 30:611-661

Deuticke B, Lutkemeier RK, Pose B (1992) Tellurite- induced damage of the erythrocyte membrane. Manifestations and mechanisms. Biochem Biophys Acta 1109:97-107

Dhakshinamoorthy S, Jain AK, Bloom DA, Jaiswal AK (2005) Bach1 competes with Nrf2 leading to negative regulation of the antioxidant response element (ARE)-mediated $\mathrm{NAD}(\mathrm{P}) \mathrm{H}$ :quinone oxidoreductase 1 gene expression and induction in response to antioxidants. J Biol Chem 280:16891-16900

Dringen R, Pawlowski PG, Hirrlinger J (2005) Peroxide detoxification by brain cells. J Neurosci Res 79:157-165

Engman L, Al-Maharik N, Mcnaughton M, Birmingham A, Powis G (2003) Thioredoxin reductase and cancer cell growth inhibition by organotellurium antioxidants. Anticancer Drugs 14:153-161 
Engman L, Kanda T, Gallegos A, Williams R, Powis G (2000) Water soluble organotellurium compounds inhibit thioredoxin reductase and the growth of human cancer cells. Anti-Cancer Drug Des 15:323-330

Engman L, Tunek A, Hallberg M, Hallberg A (1994) Catalytic effects of glutathione peroxidase mimetics on the thiol reduction of cytochrome $c$. Chem Biol Interact 93:129-137

Flora SJS, Pande M, Kannan GM, Mehta A (2004) Lead induced oxidative stress and its recovery following co-administration of melatonin or n-acetylcysteine during chelation with succimer in male rats. Cell Mol Biol 50:OL543-OL551

Franco JL, Posser T, Dunkley PR, Dickson PW, Mattos JJ, Martins R, Bainy AC, Marques MR, Dafre AL, Farina M (2009) Methylmercury neurotoxicity is associated with inhibition of the antioxidant enzyme glutathione peroxidase. Free Radic Biol Med 47:449-457

Funchal C, de Andrade RB, Turcatel E (2011) Acute treatment with the organochalcogen 3-butyl-1-phenyl-2 (phenyltelluro)oct-en-1-one produces behavioral changes and inhibition of creatine kinase activity in the brain of rats. Int J Dev Neurosci 29:903-907

Hilbert J, Mohsenin V (1996) Adaptation of lung antioxidants to cigarette smoking in humans. Chest 110:916-920

Holmgren A, Björnstedt M (1995) Thioredoxin and thioredoxin reductase. Meth Enzymol 252:199-208

Hur W, Gray NS (2011) Small molecule modulators of antioxidant response pathway. Curr Opin Chem Biol 15:162-173

Jaiswal AK (2004) Nrf2 signaling in coordinated activation of antioxidant gene expression. Free Radic Biol Med 36:1199-1207

Kim CY, Nakai K, Kasanuma Y, Satoh H (2000) Comparison of neurobehavioral changes in three inbred strains of mice prenatally exposed to methylmercury. Neurotoxicol Teratol 22:397-403

Kudin AP, Augustynek B, Lehmann AK, Kovács R, Kunz WS (2012) The contribution of thioredoxin-2 reductase and glutathione peroxidase to $\mathrm{H}(2) \mathrm{O}(2)$ detoxification of rat brain mitochondria. Biochim Biophys Acta 1817:1901-1906

Laden BP, Porter TD (2001) Inhibition oh human squalene monooxigenase by tellurium compounds: evidence of interaction with vicinal sulfhydryls. J Lipid Res 42:235-240

Lee JM, Li J, Johnson DA, Stein TD, Kraft AD, Calkins MJ, Jakel RJ, Johnson JA (2005) Nrf2, a multi-organ protector? FASEB J 19:1061-1066

Ling X, Zhang Y, Lu Y, Huang H (2011) Superoxide dismutase, catalase and acetylcholinesterase: biomarkers for the joint effects of cadmium, zinc and methyl parathion contamination in water. Environ Technol 32:1463-1470

Liu H, Wang H, Shenvi S, Hagen TM, Liu RM (2004) Glutathione metabolism during aging and in Alzheimer disease. Ann N Y Acad Sci 1019:346-349

Lowry OH, Rosebrough NJ, Farr AL, Randall RJ (1951) Protein measurement with the Folin phenol reagent. J Biol Chem 193:265

Maciel EN, Bolzan RC, Braga AL, Rocha JB (2000) Diphenyl diselenide and diphenyl ditelluride differentially affect delta-aminolevulinate dehydratase from liver, kidney, and brain of mice. J Biochem Mol Toxicol 14:310-319

Meinerz DF, Sudati JH, dos Santos DB, Frediani A, Alberto EE, Allebrandt J, Franco $J$, Barbosa NB, Aschner M, da Rocha JB (2011) Evaluation of the biological effects of (S)-dimethyl 2-(3-(phenyltellanyl) propanamido) succinate, a new telluroamino acid derivative of aspartic acid. Arch Toxicol 85:43-49

Meister A, Anderson ME (1983) Glutathione. Ann Rev Biochem 52:711-760

Meotti FC, Borges VC, Zeni JBT, Nogueira CW (2003) Potential renal and hepatic toxicity of diphenyl diselenide, diphenyl ditelluride and ebselen for rats and mice. Toxicol Lett 143:9-16

Mischell BB, Shiingi SM (1980) Selected Methods in Cellular Immunology. W.H. Freeman Company, New York, pp 1-469

Moldeus P, Cotgreave IA, Berggren M (1986) Lung protection by a thiolcontaining antioxidant: N-acetylcysteine. Respiration 50:31-42

Nogueira CW, Borges VC, Zeni G, Rocha JBT (2003) Organochalcogens effects on d-aminolevulinate dehydratase activity from human erythrocytic cells in vitro. Toxicol 191:169-178

Nogueira CW, Rotta LN, Perry ML, Souza DO, Rocha JBT (2001) Dipheny diselenide and diphenyl ditelluride affect the rat glutamatergic system in vitro and in vivo. Brain Res 906:157-163

Nogueira CW, Rotta LN, Zeni G, Souza DO, Rocha JBT (2002) Exposure to ebselen changes glutamate uptake and release by rat brain synaptossomes. Neurochem Res 27:283-288

Nogueira CW, Zeni G, Rocha JBT (2004) Organoselenium and organotellurium compounds: pharmacology and toxicology. Chem Rev 104:6255-6286

Noseworthy MD, Bray TM (1998) Effect of oxidative stress on brain damage detected by MRI and in vivo 31P-NMR. Free Radic Biol Med 24:942-951
Ogra Y, Kobayashi R, Ishiwata K, Suzuki KT (2008) Comparison of distribution and metabolism between tellurium and selenium in rats. J Inorg Biochem 102:1507-1513

Pessoto FS, Faria PA, Cunha RLOR, Comasseto JV, Rodrigues T, Nantes IL (2007) Organotellurane-promoted mitochondrial permeability transition concomitant with membrane lipid protection against oxidation. Chem Res Toxicol 20:1453-1461

Petragnani N (1994) Tellurium in organic synthesis. Academic Press, New York

Pinton S, Luchese C, Stangherlin EC, Roman SS, Nogueira CW (2010) Diphenyl Ditelluride Induces Neurotoxicity and Impairment of Developmental Behavioral in Rat Pups. J Braz Chem Soc 21:2130-2137

Sailer BL, Liles N, Dickerson S, Sumners S, Chasteen TG (2004) Organotellurium compound toxicity in a promyelocytic cell line compared to non-telluriumcontaining organic analog. Toxicol In Vitro 18:475-482

Santos DB, Schiar VPP, Paixão MW, Meinerz DF, Nogueira CW, Aschner M, Rocha JBT, Barbosa NBV (2009a) Hemolytic and genotoxic evaluation of organochalcogens in human blood cells in vitro. Toxicol In Vitro 23:1195-1204

Santos DB, Schiar VPP, Ribeiro MCP, Schwab RS, Meinerz DF, Allebrandt J, Rocha JBT, Nogueira CW, Aschner M, Barbosa NBV (2009b) Genotoxicity of organoselenium compounds in human leukocytes in vitro. Mutat Res 676:21-26

Sathish P, Paramasivan V, Palani V, Sivanesan K (2011) N-acetylcysteine attenuates dimethylnitrosamine induced oxidative stress in rats. Eur J Pharmacol 654:181-186

Savegnago L, Borges VC, Alves D, Jesse C, Rocha JBT, Nogueira CW (2006) Evaluation of antioxidant activity and potential toxicity of 1-buthyltelurenyl-2 methylthioheptene. Life Sci 79:1546-1552

Schiar VP, Dos Santos DB, Paixão MW, Nogueira CW, Rocha JB, Zeni G (2009) Human erythrocyte hemolysis induced by selenium and tellurium compounds increased by GSH or glucose: a possible involvement of reactive oxygen species. Chem Biol Interact 177:28-33

Schülke S, Dreidax D, Malik A, Burmester T, Nevo E, Band M, Avivi A, Hankeln T (2012) Living with stress: Regulation of antioxidant defense genes in the subterranean, hypoxia-tolerant mole rat, Spalax. Gene 500:199-206

Stangherlin EC, Favero AM, Zeni G, Rocha JBT, Nogueira CW (2005) Teratogenic vulnerability of Wistar rats to diphenyl ditelluride. Toxicol 2:231-239

Subramanian MV, James TJ (2010) Age-related protective effect of deprenyl on changes in the levels of diagnostic marker enzymes and antioxidant defense enzymes activities in cerebellar tissue in Wistar rats. Cell Stress Chaperones 15:743-751

Tanito M, Agbaga MP, Anderson RE (2007) Upregulation of thioredoxin system via Nrf2-antioxidant responsive element pathway in adaptive-retinal neuroprotection in vivo and in vitro. Free Radic Biol Med 42:1838-1850

Taylor A (1996) Biochemistry of tellurium. Biol Trace Elem Res 55:231-239

Wang X-J, Zhang DD (2009) Ectodermal-neural cortex 1 down-regulates Nif2 at the translational level. PLoS One 4:e5492. doi:10.1371/journal.pone.0005492

Wendel (1981) A Glutathione peroxidase. Methods Enzymol 77:325-333

\section{doi:10.1186/2193-1801-2-182}

Cite this article as: Meinerz et al:: Sub-acute administration of (S)dimethyl 2-(3-(phenyltellanyl) propanamido) succinate induces toxicity and oxidative stress in mice: unexpected effects of $\mathrm{N}$-acetylcysteine. SpringerPlus 2013 2:182

\section{Submit your manuscript to a SpringerOpen ${ }^{\odot}$ journal and benefit from:}

- Convenient online submission

Rigorous peer review

- Immediate publication on acceptance

- Open access: articles freely available online

- High visibility within the field

- Retaining the copyright to your article

Submit your next manuscript at $>$ springeropen.com 